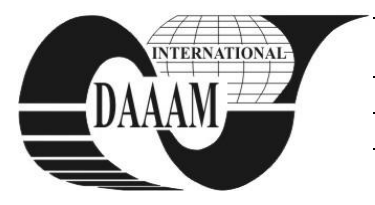

\title{
ENSURING FAIR WAGES AND ETHICAL CONSUMPTION THROUGH THE DETERMINATION OF MINIMUM ACCEPTABLE PAYMENT AND COST OF SUSTAINABLE PRODUCTION
}

\author{
JOITA, A[lin] - C[ristian]; COSTACHE, S[orina]; DARZAN, M[ihaela] \& CRISTIAN, E[lena] R[aluca]
}

\begin{abstract}
Fair Trade is a trading partnership, based on dialogue, transparency and respect, that seeks greater equity in international trade. It contributes to sustainable development by offering better trading conditions to, and securing the rights of, marginalized producers and workers. The food price surge of 2008-2012 highlighted the difficulty of achieving an efficient food security policy framework which can be coherent and relevant both when the prices are low and when they sharply rise. Since 2008 we are facing the greatest economic slowdown in history, thus it is absolutely clear that the situation will only worsen. In this context, our paper aims to analyze the possible alternative given by the Fair Trade system. The article targets smallholders in agriculture and industryand presents software models for determining fair payments and costs of sustainable production in order to reduce poverty and optimize the production cycle[1]. This is motivated by the fact that according to the Rome Declaration on World Food Security, more than 800 million people throughout the world do not have enough food to meet their basic nutritional needs, even though food supplies have increased substantially.
\end{abstract}

Keywords:Fairtrade, minimum price for sustaining production, COSP, fair wage, smallholder farmers

\section{INTRODUCTION}

Fair Trade is a trading partnership, based on dialogue, transparency and respect, that seeks greater equity in international trade. It contributes to sustainable development by offering better trading conditions to, and securing the rights of, marginalized producers and workers - especially in the South.

Fair Trade organizations have a clear commitment to Fair Trade as the principal core of their mission. They, backed by consumers, are engaged actively in supporting producers, awareness raising and in campaigning for changes in the rules and practice of conventional international trade. Though it started as a social movement generated by the market, Fair Trade today is a global movement.

Over a million small-scale producers and workers are organized in as many as 3,000 grassroots organizations and their umbrella structures in over 50 countries in the South. Their products are sold in thousands of Worldshops or Fair Trade shops, supermarkets and many other sales points in the North and, increasingly, in sales outlets in the Southern hemisphere.

The food price surge of 2008-2012 highlighted the difficulty of achieving an efficient food security policy framework which can be coherent and relevant both when the prices are low and when they sharply rise.
While in the pre-food price surge period, farmers, especially those from developing countries, claimed the need for subsidies and market intervention in order to stabilize their incomes. Now, with prices rapidly increasing, food insecurity itself has become a stringent world issue that requires rapid and coordinated solutions. According tothe Rome Declaration on World Food Security: more than 800 million people throughout the world do not have enough food to meet their basic nutritional needs, even though food supplies have increased substantially. The problems of hunger and food insecurity have global dimensions and are likely to persist, and even increase dramatically in some regions, unless urgent, determined and concerted action is taken, given the anticipated increase in the world's population and the stress on natural resources.

Taking into account the multiple challenges presented above and the fact that since 2008 we are facing the greatest economic slowdown in history, it is absolutely clear that the situation will only worsen. In this context, our paper aims at analyzing the possible alternative given by the Fair Trade system. When prices were low, fair trade ensured equitable prices to farmers in developing countries. Now, when the challenge is highly increasing food prices, consumers and producers alike need to be conscious of the ripple effect of their purchase decision. In the end, disregarding the prices' volatily, fair trade might be an alternative for consumers and producers to become more socially responsible, thus achieving food security and welfare in developing countries[2].

This paper tackles extremely stringent issues for developing countries. Food prices instability that bring about food insecurity, famine, disease, poverty and higher criminal rates are not simple data that fill up endless statistics. The solution analyzed in our paper, based upon the consolidation of the fair trade system, could become an alternative, regardless of food prices' levels.

\section{ETHICAL CONSUMPTION}

The UK is the world's biggest Fair Trade market, and it continues to grow. The first three products to showcase the Fairtrade mark hit the shelves in this country 18 years ago. Now there are more than 4,500 products carrying the familiar logo in British shops.

Sales of fairly traded products have bucked the trend of decline in the UK retail market to grow by $12 \%$ in the 
last year. The value of Fairtrade products sold through shops reached $£ 1.32 \mathrm{bn}$ in 2011 , compared to $£ 1.17 \mathrm{bn}$ in 2010, according to Fig.s from the Fairtrade Foundation.

Unlike other premium sectors such as the organic market, which have lost ground as consumers struggle with the combination of rising food and energy prices and stagnant incomes, the Fairtrade market has continued to expand. Sales of Fairtrade products are on the rise around the world, with the US leading the charge in ethical consumerism. New data showed that overall sales of Fairtrade products grew by 24 percent last year.

\subsection{The US market}

When discussing the subject of ethical consumption, it is important to underline the fact that "ethical" is a broad, flexible and often highly personal term when consumers apply it to food purchased in supermarkets or specialty stores. Ethical food is defined by a number of attributes and perceived benefits regarding how a food is produced or processed, its impact on the environment, adherence to quality and safety standards, and even where food is sold and how it is priced.

According to a 2010 survey, the US Fairtrade market has the following characteristics.

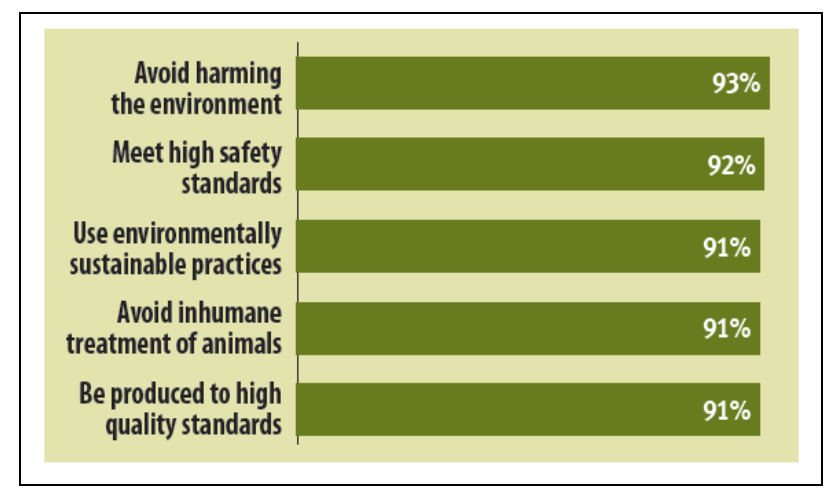

Fig. 1. In order to qualify as an "ethical food," a food (or food producer) should:(see Fig.)

Source: "Ethical Food", a 2010 Report by Context Marketing

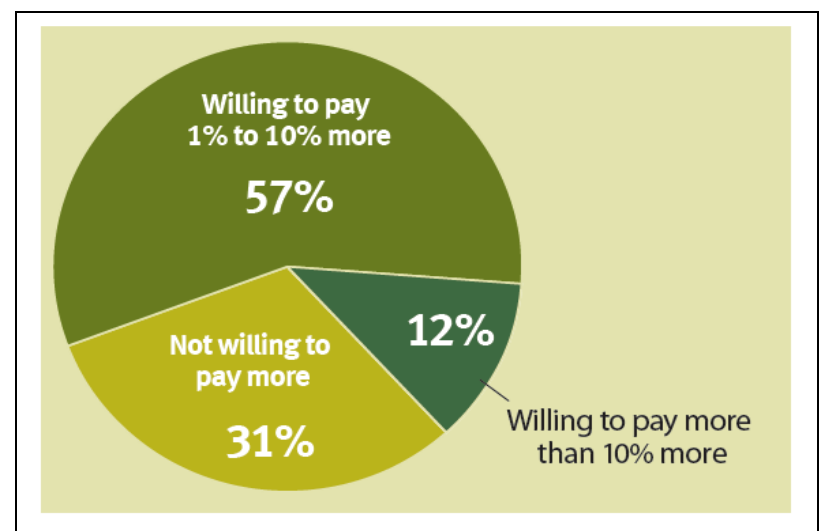

Fig. 2. "How much more are you willing to pay for food that promises to be produced to higher ethical standards?"

Source: "Ethical Food", a 2010 Report by Context Marketing

According to the first two Fig.s, ethical claims help consumers identify high quality, safer foods. While many consumers want their food purchases to help make the world a better place, such as by protecting the environment and improving the treatment of farm animals, they also find that credible ethical food claims assure them about food quality and safety. When asked to define the qualities of an "ethical food," most consumers readily emphasize health and safety benefits along with more altruistic concerns.

\begin{tabular}{|ll|}
\hline $69 \%$ & $\begin{array}{l}\text { Willing to pay more for food produced } \\
\text { to higher ethical standards }\end{array}$ \\
\hline $65 \%$ & $\begin{array}{l}\text { More willing to believe brand claims about high } \\
\text { quality when I know a food is ethically produced }\end{array}$ \\
\hline $58 \%$ & $\begin{array}{l}\text { More willing to take the time to learn } \\
\text { about ethically produced food brands }\end{array}$ \\
\hline $55 \%$ & $\begin{array}{l}\text { More likely to recommend ethically } \\
\text { produced food brands and products }\end{array}$ \\
\hline $44 \%$ & $\begin{array}{l}\text { Stopped buying a brand because I learned } \\
\text { the company producing it was acting in a } \\
\text { socially irresponsible or unethical way }\end{array}$ \\
\hline $43 \%$ & $\begin{array}{l}\text { Feel virtuous when purchasing } \\
\text { ethically produced foods }\end{array}$ \\
\hline $42 \%$ & $\begin{array}{l}\text { More loyal to ethically produced food } \\
\text { brands than other brands }\end{array}$ \\
\hline
\end{tabular}

Fig. 3. Ethical brand behavior builds consumer engagement Source: "Ethical Food", a 2010 Report by Context Marketing

Fig. 3 shows that ethical foods build brand engagement. When consumers find ethical claims credible and relevant, they often develop a deeper emotional connection with the brand. Many consumers report that they are more willing to learn about ethically produced foods and recommend them to others, and are more likely to believe other quality claims made by the brand. Most important, 69\% of consumers report they will pay more for food brands they see as "ethical."

\begin{tabular}{|l|c|c|}
\hline $\begin{array}{l}\text { Believe we need to apply } \\
\text { human standards to the care } \\
\text { of farm animals }\end{array}$ & Female & Male \\
\hline $\begin{array}{l}\text { Want food producer assurance } \\
\text { that farm workers are treated } \\
\text { fairly and are well cared for }\end{array}$ & $76 \%$ & $67 \%$ \\
\hline $\begin{array}{l}\text { Want to know if food contains } \\
\text { ingredients from cloned or } \\
\text { genetically engineered animals } \\
\text { or plants }\end{array}$ & $75 \%$ & $68 \%$ \\
\hline $\begin{array}{l}\text { Have more confidence in food sold } \\
\text { in grocery stores that actively } \\
\text { support ethical and sustainable } \\
\text { farming practices }\end{array}$ & $73 \%$ & $65 \%$ \\
\hline $\begin{array}{l}\text { Believe food grown on small } \\
\text { sustainable farms is safer to eat }\end{array}$ & $51 \%$ & $44 \%$ \\
\hline \begin{tabular}{l} 
Y. \\
\hline
\end{tabular} & \\
\hline
\end{tabular}

Fig. 4. Younger adults place greater emphasis on ethical foods Source: "Ethical Food", a 2010 Report by Context Marketing

Women and younger adults are more responsive to ethical claims. While there is broad agreement on the importance of ethical foods among men and women in all 
age groups, women are generally more responsive to ethical claims for altruistic as well as health and safety reasons, and are willing to pay a little more for ethically produced food. Younger adults also are more attentive to many ethical claims than their older counterparts and are more likely to act on those beliefs when it comes to food purchases.

\section{a. The UK market}

Retailers and producers who have continued to convert to Fairtrade and to sell sustainable produce during the downturn are helping to maintain ethical sales growth [3]. According to a 2011 report, which has been tracking shopping trends for more than a decade, it has been showed that despite the economic downturn, sales of ethical goods and services have remained resilient, going up almost $9 \%$ last year from $£ 43$ bn to $£ 46.8 \mathrm{bn}$. Acting as a barometer of green spending since 1999 when annual ethical sales were just $£ 13.5 \mathrm{bn}$, the report analyses sales data for various sectors including food, household goods, eco-travel and ethical finance.

However, not all ethical expenditure increased. Sales of organic food were down $10 \%$ year on year at $£ 1.53 \mathrm{bn}$, which means it has decreased $23 \%$ since its peak of $£ 1.99$ bn in 2008. Intervention by enlightened businesses, together with regulatory intervention, is now driving ethical sales growth. During the downturn we've seen some of the biggest ever Fairtrade conversions, be it in chocolate or sugar, and business is beginning to respond to the challenge to provide consumers with more sustainable products and services such as fish, palm oil and soya.

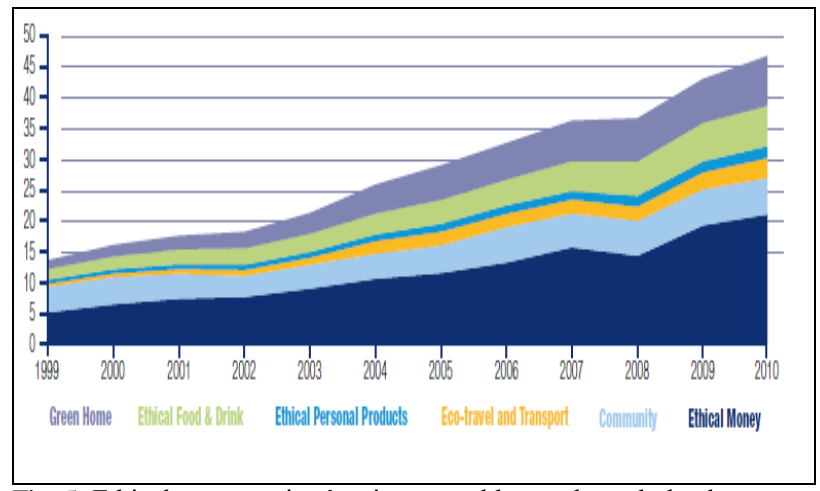

Fig. 5. Ethical consumerism's winners and losers through the downturn Source: "Ethical Consummerism Report 2011", the Co-operative Group and ECRA

\begin{tabular}{|l|l|}
\hline Winners & Losers \\
\hline Fairtrade & Organic food \\
\hline Ethical money & Rechargeable batteries \\
\hline Sustainable fish & Ethical clothing \\
\hline
\end{tabular}

Fig. 6. Ethical spending in the UK 1999-2010, £bn

Source: "Ethical Consumerism Report 2011", the Co-operative Group and ECRA

The report stresses the fact that "ethical consumers are still a vitally important barometer of change; however, the actions of progressive business are now a significant contributor to sales growth. At the same time, ethical expenditure remains relatively small when compared to overall spending. Ultimately, over and above the efforts of responsible business and ethical consumers, sustainable solutions require a government committed to long term intervention, such as an effective feed-in tariff programme, to maintain the economic viability of the micro-generation market".

\section{FAIRTRADE TOOLS}

\subsection{Cost of Sustaining Production}

One of the challenges inFairtrade is to obtain a price that is appealing to the customer and, at least, break-even and cover the costs generated over the entire production chain.

A DSS model in cost management for the entire production chain isvital, especially for small holders. To this extent, the authors propose a multi-tier client-server architecture model, designed with user-friendly interface, for personnel with low experience in IT. This allows the user to form a decision, on the account of results received from the application, based onspecific processing and validation rules. The software platform is divided into two main components:the DSS structure presented in fig. 7(a) and the technological transfer modules shown in fig. 7(b).

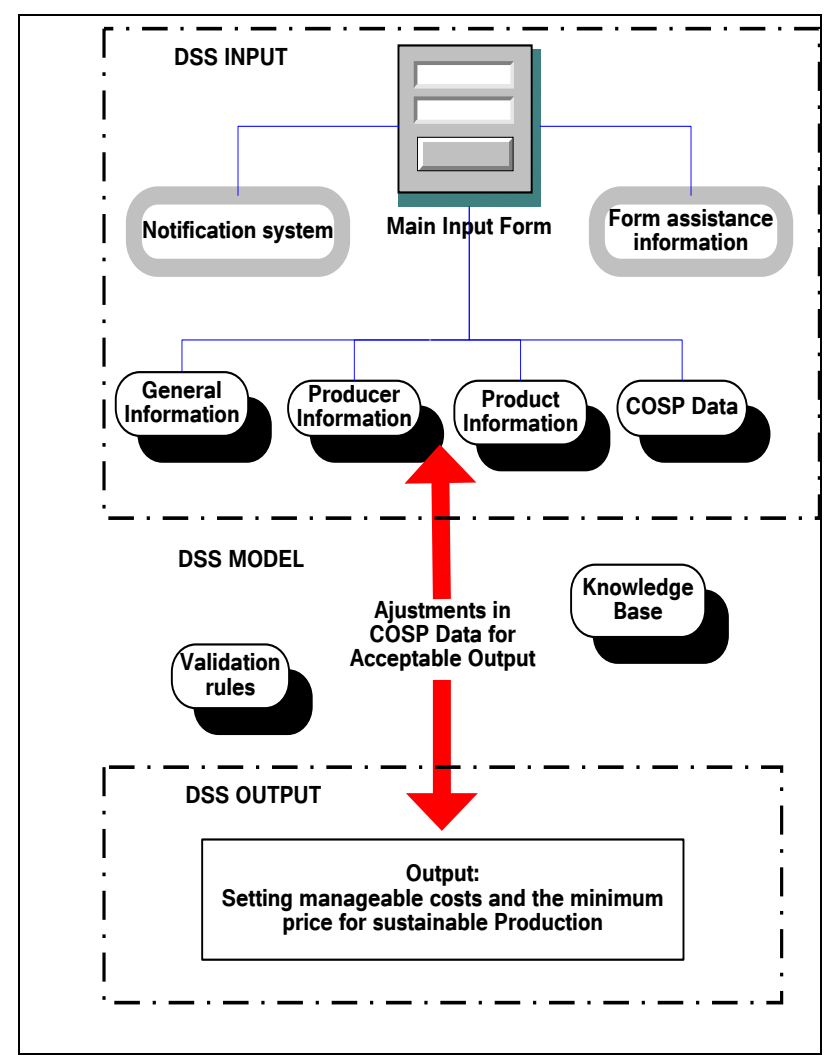

Fig. 7(a). Decision Support System Structure

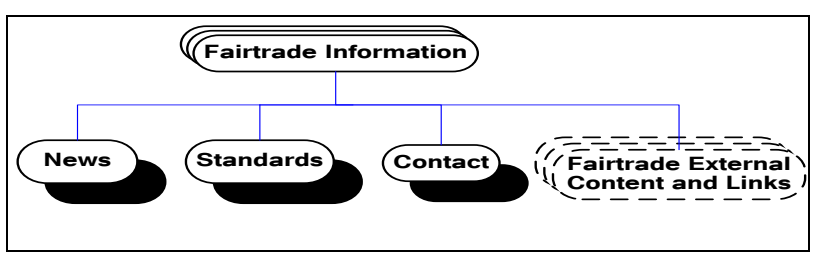

Fig. 7(b). Technological Transfer System Structure 
The input and output interfaces have both dynamic and static content, integrated as stated in[4] and [5]. In order to maintain good functionality and compatibility among most of the browsers and their versions, standard client-side web technologies, such as HTML, CSS and JavaScript are recommended to be used in implementation [6],[7],[8].Application Logic is described in Fig. 9.

The DSS system provides technological transfer through the Fairtrade Information module and it offers assistance by contextual help. Before inserting the data for calculating Cost of Sustainable Production (COSP),the header should be filled-in withGeneral, Producer, and Product Information. Definition and general structure of a DSS can be found in [9] and [10].

One should take into consideration the agricultural period and production cycle on completingGeneral Information. If production cycle input field is filled-in thenthe crop is of a perennial kind.

In this calculation one can expect an uneven yearly cash flow, if between harvesting and planting more than one year passes. This is a good enough reason to insert a field for input of the entire cycle value.

The Producer and Product Information sections contain descriptive fields that may be used, after storing the data in a database, to generate reports on producers, products owned or harvested by a certain producer, their COSP, identify trends to generate forecasts etc.

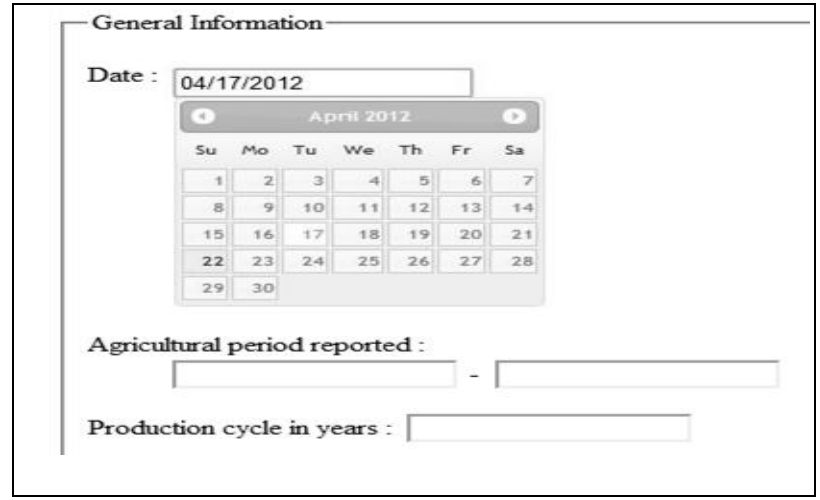

Fig. 8. DSS Interface - General Information

COSP Data is collected from various stages of production related to:

a. Establishment (initial investment);

b. Field operations;

c. Harvest and post-harvest;

d. Transformation and/or processing ;

e. Product preparation and/or packaging;

f. Central structure (umbrella organization) activities;

g. Export costs.

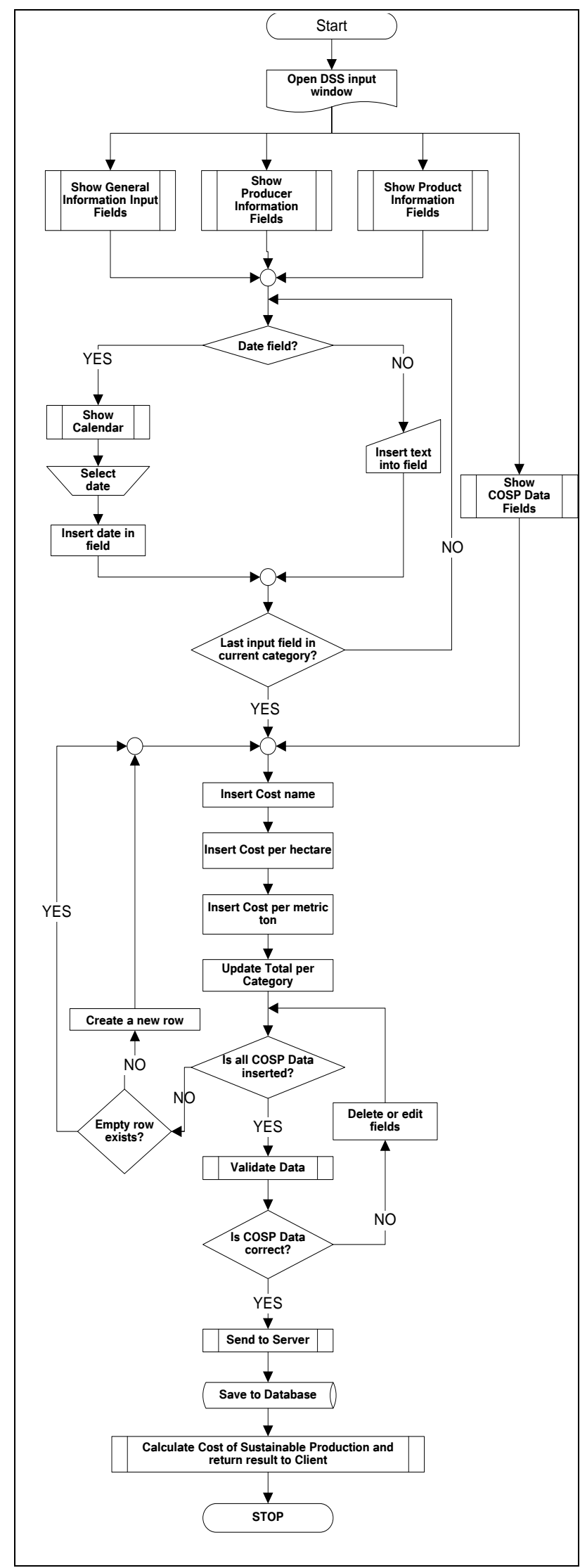

Fig. 9. Application Logic Scheme

For the first five stages, COSP Data is delimited into three types of costs: "Labor", "Inputs and Services", "Capital and investment".

The model has to be as general as to manage cases when some activites may not take place at the producer's 
level. According to these requirements, all fields in the COSP Data section are optional. Also, the interface is flexible and allows addition or removal of extra fields.

In order to assist the producer in making a decision regarding the minimum fair price, at the end of every section, the application displays in real-time totals and amortization values per hectare and per metric ton.Also, a report with recommendations is displayed after the date is sent to the server and processed. The data is modifiable at any stage, thus allowing a What-If analysis. This instrument is also useful as an integrated module in a virtual business incubator, as presented in [11].

This application proposalcan offer smallholders a starting point in price negotiations between producer and purchaser or express the level of costs that maintain a sustainable production.

\subsection{Fair-payment Calculator}

The Fair-payment calculator is a web application designed to set a standard methodologyfor payment calculation according to the local payment rates. This can return the value for a fair compensationof an employed service, even though the person being employed is not in the same region or country. As stated in [12], [13] and [14], the price of the same service or product can differ by various factors, such as the geographical location, purchasing power parity, national and international taxes etc.

Input interface model requires the following fields:

- country where the product or service is provided;

- living environment of the Contractor: urban or rural;

- total payment to the Contractor, with a choice for currency;

- time spent by the Contractor to provide the service or create one unit of the product;

- cost of raw materials;

- quantity of raw materials.

In our client-server architecture, the use case for submitting information can be presented as such: when the user submits the Input Form,the information is stored to database by processes situated server-side, on thedatalogic tier.On the same level, scripts enable necessary calculations. Resultsarereturned to the presentation tier, client-side, where an interface is created with this new data. The interface is shown in Fig. 10.
The result is represented per day or per month (left frame), in the currency selected at a previous step by the user. In the same webpageindicators are generated that compare the daily payment returned by the system to poverty indicators, national and international (right frame): Minimum Fair Payment, International Poverty Line, Non-Poverty Wage and $\$ 4$ a day poverty line. Deviantions are outputted in the field named Differences while Raise Payment and Reduce Time quantifies the difference from the minimum fair payment.

To obtain a clearer view of the model and the results, indicator values are described in a greater depth:

a. Minimum Wage (National) - obtained from International Labour Organization database [15], for unskilled workers.It can be a set of one or two values, depending on the country. The input form can take both cases, two values meaning a differentiation in rural and urban areas.

b. International Poverty Line - an indicator set by the World Bank.The model will use 2 international dollars a day as a default value, following the recommendation in [16] and [17]. The PPP conversion factor resides at[18].

c. Non-poverty wage - this indicator states the country's economic development level. The result represents the number of dollars per daythat allow a fulltime worker to raise a family out of poverty [19]. The formula uses the factor of purchasing power parity and the hourly wage found in poverty guidelines of U.S. Department of Health and Human Services. The prototype uses information from [20], [21] and [22]. Alternatively, a list can be found at [23].

d. The last indicator " $\$ 4$ a day poverty line" is close to the poverty line for developed countries and is the minimum value recommended in [24] and [25].

\section{CONCLUSION}

These Fairtrade instruments assist in decision-making processes in production and wage payment. They contribute to a better understanding of the labour market and to the costs of sustaining production. Future development will include a Knowledge Management System to store topic oriented information and archive calculations in order to raise the quality of the results and forecasts on the evolution of costs and salaries.

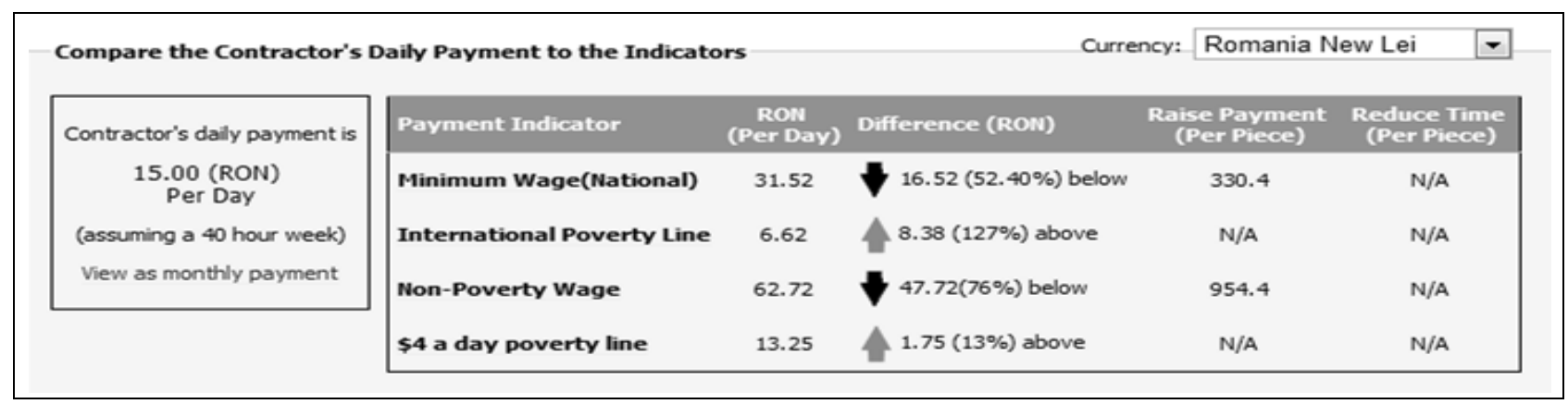

Fig. 10. Fair Payment - Results Interface Model 


\section{ACKNOWLEDGEMENTS}

This article is a result of the project POSDRU/88/1.5./S/55287 „Doctoral Programme in Economics at European Knowledge Standards (DOESEC)". This project is co-funded by the European Social Fund through The Sectorial Operational Programme for Human Resources Development 20072013, coordinated by The Bucharest Academy of Economic Studies in partnership with West University of Timisoara.

\section{REFERENCES}

[1] Wessely, E.; Vargova, J. \& Paulikova, A. (2009). Environmental Engineering and Environmental Management Support Sustainable Development in Industry, Annals of DAAAM for 2009 \& Proceedings of the 20th International DAAAM Symposium, 25 28th November 2009, Vienna, Austria, ISSN 1726-9679, ISBN 978-3-901509-70-4, Katalinic, B. (Ed.), pp. 1355-1356, Published by DAAAM International Vienna, Vienna

[2] Popa, C.; Beizadea, H.; Nicolae, F. \& Nistor, F. (2010). A New Model for the Contemporary Market Prices Mechanism, Annals of $D A A A M$ for 2010 \& Proceedings of the 21st International DAAAM Symposium, 20-23rd October 2010, Zadar, Croatia, ISSN 1726-9679, ISBN 978-3-901509-73-5, Katalinic, B. (Ed.), pp. 1349-1350, Published by DAAAM International Vienna, Vienna

[3] Draghici, A.; Izvercianu, M. \& Barglazan, D. (2008). Aspects of Green Business Development, Annals of DAAAM for 2008 \& Proceedings of the 19th International DAAAM Symposium, 2225th October 2008, Trnava, Slovakia, ISSN 1726-9679, ISBN 978-3-901509-68-1, Katalinic, B. (Ed.), pp. 0407-0408, Published by DAAAM International Vienna, Vienna

[4] Căruțaşu, G.; Botezatu, C.; Ionescu, S.; Botezatu, P. \& Joița, A. C. (2011). Sisteme Integrate Informatice Pentru Management. Editura Universitară, ISBN 978-606-591-106-2, București

[5] Căruțașu, G.; Botezatu C.-P. \& Joița, A. C. (2009). Managing Unstructured Data in Implementation of the Integrated Management System (DI - IMS). Proceedings of the 16th International Economic Conference, Sibiu, Romania, ISBN 978973-739-775-1, pp. 10-16, Published by "Lucian Blaga University" Publishing House, Sibiu

[6] Boicea, A.; Magdalina, C.; Ionescu, D. - C.; Radulescu, F. \& Popa, G. D. (2011). An Architecture for Distributed Databases on Workstations, Annals of DAAAM for 2011 \& Proceedings of the 22nd International DAAAM Symposium, 23-26th November 2011, Vienna, Austria, Volume 22, No. 1, ISSN 1726-9679, ISBN 9783-901509-83-4, Katalinic, B. (Ed.), pp. 0121-0122, Published by DAAAM International Vienna, Vienna

[7] Garais, G. E. \& Enaceanu, A. S. (2011). Determining Quality Levels for Improving Maintenance Processes, Annals of DAAAM for 2011 \& Proceedings of the 22nd International DAAAM Symposium, 23-26th November 2011, Vienna, Austria, Vol. 22, No. 1, ISSN 1726-9679, ISBN 978-3-901509-83-4, Katalinic, B. (Ed.), pp. 1321-1322, Published by DAAAM International Vienna, Vienna

[8] Dinuca, C. E.; Ciobanu, D. \& Istrate, M. (2011). A Method for Improving the Prediction of Next Page Request of a Web User, Annals of DAAAM for 2011 \& Proceedings of the 22nd International DAAAM Symposium, 23-26th November 2011, Vienna, Austria, Vol. 22, No. 1, ISSN 1726-9679, ISBN 978-3901509-83-4, Katalinic, B. (Ed.), pp. 1443-1444, Published by DAAAM International Vienna, Vienna.

[9] Antonopoulou, E;Karetsos, S.T.; Maliappis, M. \& Sideridis, A.B.(2010). Web and mobile technologies in a prototype DSS for major field crops, Computers and Electronics in Agriculture, Vol. 70, No. 2, pp. 292-301, ISSN 0168-1699

[10] PERINI, A. \& SUSI, A.(2004). Developing a decision support system for integrated production in agriculture. Environmental
Modelling \& Software, Vol. 19, No. 9, pp. 821-829, ISSN 13648152

[11] Joița, A.C.; Căruțașu, G.\&Botezatu, C. P.(2010).Technology and business incubator centers - adding support to small and medium enterprises in the Information Society,Proceedings of the 17th International Economic Conference The Economic World Destiny: Crisis and Globalization?, 13-14 ${ }^{\text {th }}$ May, Sibiu, Romania, ISBN 978-973-739-987-8, pp. 107-115,Published by"Lucian Blaga University" Publishing House, Sibiu

[12] Andersson, T.; Svensson, L.-G. \& Yang, Z. (2010). Constrainedly fair job assignments under minimum wage. Games and Economic Behavior, Vol. 68, No. 2, pp. 428-442, ISSN 0899-8256

[13] Hart, R. A. \&Ma, Y. (2010). Wage-hours contracts, overtime working and premium pay,Labour Economics, Vol. 17, No. 1, pp. 170-179, ISSN 0927-5371

[14] Sachiko, K. \& Isamu, Y. (2012).Impact of overtime regulations on wages and work hours, Journal of the Japanese and International Economies, Vol. 26, No. 2, ISSN: 0889-1583

[15] http://www.ilo.org/global/statistics-and-databases/lang-en/index.htm, (2012). ILO Statistics and Databases,Accessed on: 2012-03-05

[16] Alam, A; Murthi, M.; Yemtsov, R.; Murrugarra E. \& Dudwick N., (2005). Growth, poverty and inequality - Eastern Europe and the Former Soviet Union, The International Bank for Reconstruction and Development / The World Bank, ISBN: 0-8213-6193-7

[17] http://go.worldbank.org/C9GR27WRJ0, (2010). World Bank, World Bank Updates Poverty Estimates for the Developing World, Accessed on: 2012-04-02

[18] http://unstats.un.org/unsd/mdg/SeriesDetail.aspx?srid=699, (2012). United Nations, Statistical Database of the Economic Commission for Europe,Accessed on: 2012-04-05

[19] http://www.sweatfree.org/vocab,(2012). SweatFreeCommunities, Campaign Vocabulary,Accessed on: 2012-04-05

[20] http://aspe.hhs.gov/poverty, (2012). Census Bureau \&Assistan Secretary For Planning and Evaluation - Department of Health\& Human Studies, 2012 HHS Poverty Guidelines: One Version of the [U.S.] Federal Poverty Measure, Accessed on: 2012-04-06

[21] http://www.imf.org/external/pubs/ft/weo/2012/01/weodata/index. aspx, (2012). International Monetary Fund, World Economic Outlook Database - World Economic and Financial Surveys, Accessed on: 2012-04-06

[22] http://www.oanda.com/rates/currency-data, (2012).OANDA Corporation, OANDA - Exchange rate data in CSV, Accessed on: 2012-04-06

[23] http://www.ci.mil.wi.us/ImageLibrary/Groups/doaPurchasing/for ms/nonpovertywage.pdf,(2008). Milwaukee County Information Office - United States of America, Non Poverty Wage Table, Accessed on: 2012-04-06

[24] Cioca, L. - I.; Cioca, M. \& Cioca, A. (2009). Using Web Engineering and Programming Languages in Documents Management, Annals of DAAAM for 2009 \& Proceedings of the 20th International DAAAM Symposium, 25-28th November 2009, Vienna, Austria, ISSN 1726-9679, ISBN 978-3-901509-70-4, Katalinic, B. (Ed.), pp. 1399-1400, Published by DAAAM International Vienna, Vienna

[25] http://siteresources.worldbank.org/INTROMANIA/Resources/Ro mania_Snapshot.pdf, (2012).World Bank, World Bank - Romania Partnership Program Snapshot - April 2012,Accessed on: 2012 04-06 